
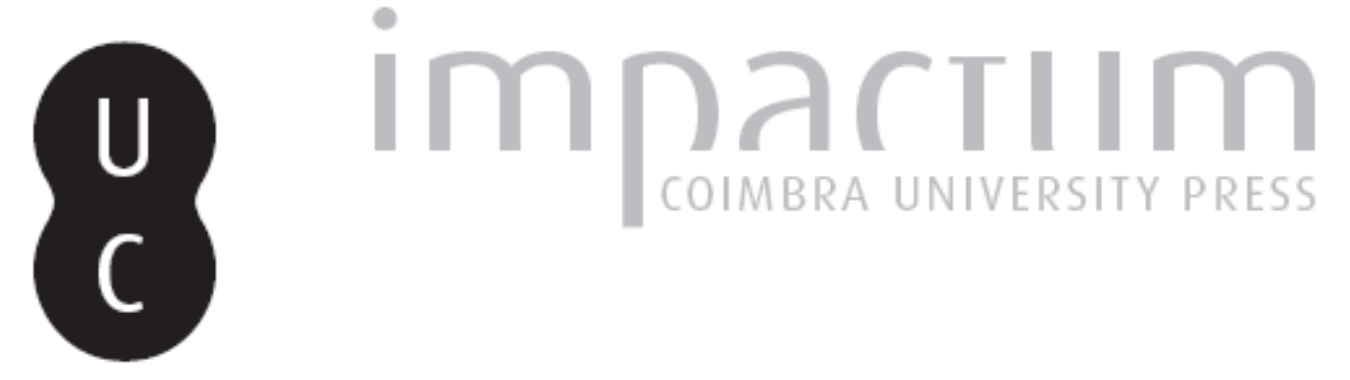

\title{
Ideal republicano e reforma da Universidade de Coimbra
}

Autor(es): $\quad$ Rodrigues, Alice Correia Godinho

Publicado por: Imprensa da Universidade de Coimbra

URL persistente:

URl:http://hdl.handle.net/10316.2/45077

DOI:

DOI:https://doi.org/10.14195/2183-8925_7-2_8

Accessed : $\quad$ 26-Apr-2023 11:50:41

A navegação consulta e descarregamento dos títulos inseridos nas Bibliotecas Digitais UC Digitalis, UC Pombalina e UC Impactum, pressupõem a aceitação plena e sem reservas dos Termos e Condições de Uso destas Bibliotecas Digitais, disponíveis em https://digitalis.uc.pt/pt-pt/termos.

Conforme exposto nos referidos Termos e Condições de Uso, o descarregamento de títulos de acesso restrito requer uma licença válida de autorização devendo o utilizador aceder ao(s) documento(s) a partir de um endereço de IP da instituição detentora da supramencionada licença.

Ao utilizador é apenas permitido o descarregamento para uso pessoal, pelo que o emprego do(s) título(s) descarregado(s) para outro fim, designadamente comercial, carece de autorização do respetivo autor ou editor da obra.

Na medida em que todas as obras da UC Digitalis se encontram protegidas pelo Código do Direito de Autor e Direitos Conexos e demais legislação aplicável, toda a cópia, parcial ou total, deste documento, nos casos em que é legalmente admitida, deverá conter ou fazer-se acompanhar por este aviso.

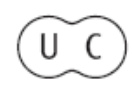




\section{REVISTA DE HISTORIA DAS IDEIAS 7}

\section{REVOLTAS E REVOLUCOẼS}

\section{**}

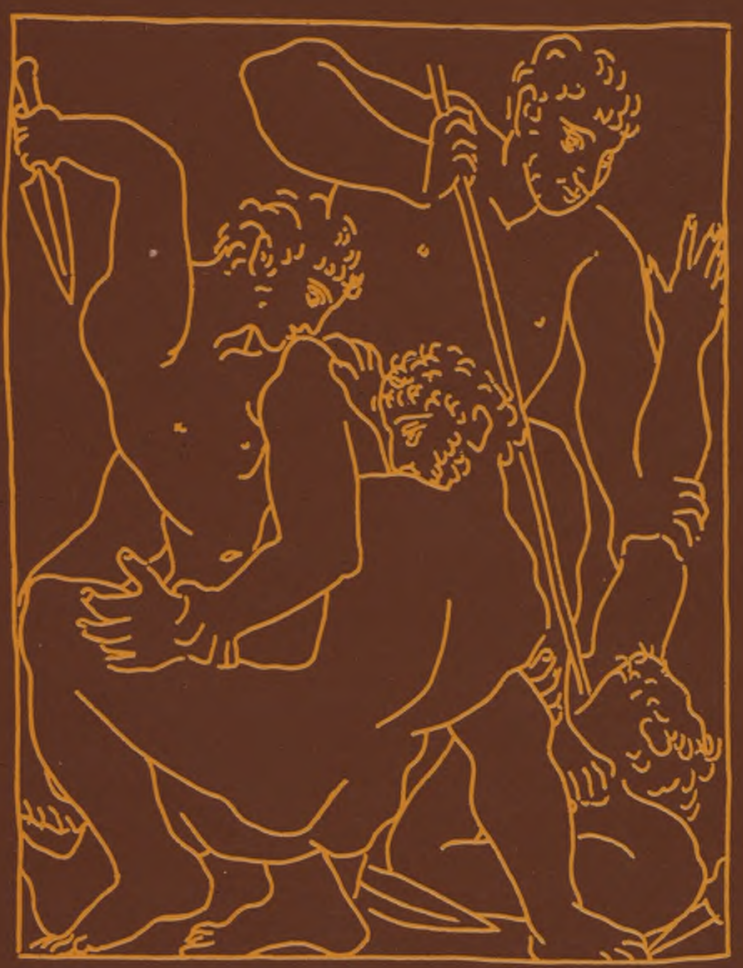

INSTITUTO DE HISTÓRIA E TEORIA DAS IDEIAS FACULDADE DE LETRAS 


\section{IDEAL REPUBLICANO E REFORMA DA UNIVERSIDADE DE COIMBRA**}

Nos fins do século XIX, mais precisamente no período que medeia entre 1883 e 1910, a vida académica sofreu um dos tempos mais conturbados da sua existência.

A Universidade não era mais do que o reflexo da decadência de uma pátria, carecida de um programa governativo, a viver ao sabor de uma política de improvisações com soluções que por vezes estavam longe de resolver as necessidades nacionais. Inseridos nesta Universidade que pouco lhes dava, os estudantes reclamavam uma nova reforma dos estudos, a liberdade de reunião e a manutenção de uma Associação onde aprendessem a decidir-se e a determinar-se 0). Acompanham-nos nestas aspirações quer os mestres republicanos quer os «avançados monárquicos». Todos sentem a necessidade urgente de uma reforma. Em 16 de Outubro de 1883, Bernardino Machado, lente catedrático da Faculdade de Filosofia, na sua Oração de Sapientia $\left({ }^{2}\right)$ proferida na Sala dos Capelos diz bem alto que a «Universidade tem que ir na vanguarda da legião que entre nós propugna pela causa do futuro; a ela compete dar o exemplo de todas as coragens e expôr-se a tudo para que não resvale das

* Arquivo da Universidade de Coimbra.

** Este tema tem sido abordado sob várias perspectivas. Por ex. Santana Dionisio, in Seara Nova, n.os 1378-79-80, de Agosto-Setembro-Outubro de 1960, fez sobre ele um estudo apropriado.

C) A Associação Académica teve a sua origem na Academia Dramática que durante muitos anos funcionou no antigo Colégio de S. Paulo. Daí saíram os nossos maiores homens públicos, conhecidos através dos seus movimentos e das suas lutas. Vide Jornal Resistência, 11 de Fevereiro de 1900.

(2) Vide Anuário da Universidade de Coimbra, vol. LXXVII-LXXVIII, 1883-1884, pp. 13-20. 


\section{Revoltas e Revoluções}

mãos (Testa nação o estandarte em que se lê: pela verdade, pelo belo e pelo bem.... O mestre tem sempre que aprender com o discípulo, quando não seja outro o melhor conhecimento do ensino, que é nada menos que o conhecimento das suas funções pedagógicas; os discípulos na intimidade dos seus mestres habituam-se a serem sinceros, a não encobrirem a sua ignorância a serem modestos, a não se iludirem e desvanecerem com o seu aproveitamento...» $\left({ }^{3}\right)$.

Em 1885, Bernardino Machado, de colaboração com António Viegas, Lente de Prima, Decano e Director da Faculdade, envia diversos pareceres sobre a reforma da Faculdade de Filosofia; no entanto só em 18 de Fevereiro de 1892, o Ministério da Instrução Pública considerando que se deve proceder sem demora à reforma universitária ordena ao reitor que, ouvido os Conselhos das Faculdades, responda aos seguintes quesitos:

1-Qual tem sido a frequência dos estudantes em cada cadeira das diferentes Faculdades nos últimos cinco anos.

2 - Qual o pessoal docente que poderá ser diminuído com a reforma dos métodos de ensino, ou com a melhor distribuição das matérias.

3 - Quais os melhoramentos que devem ser introduzidos nos quadros das respectivas disciplinas.

4 - Quais as reduções que poderão fazer-se nas verbas orçamentais destinadas para o material tanto da Universidade como dos estabelecimentos anexos $\left({ }^{4}\right)$.

$\mathrm{Na}$ década de setenta começaram a surgir em Portugal os agrupamentos republicanos e socialistas cuja agressividade e combatividade aumentava de dia para dia. De salientar que em 1878 foi eleito o primeiro deputado republicano às Cortes, Rodrigues de Freitas, eleito pelo Porto, e em 1879 se realiza o Congresso Socialista Português. Os jovens para quem a monarquia constitucional já nada dizia sentiam-se atraídos pela novas ideologias. Os próprios monárquicos lutavam também por um novo

C) Da maneira como Bernardino Machado se devotara ao ensino, Ramalho Ortigão diz. «....este jovem professor da Universidade tem uma reputação estabelecida de grande talento e vasta erudição. É citado como um dos tipos mais perfeitos do erudito moderno, prófugo do metafisismo universitário, retórico e caturra, versado em toda a história de experimentalismo das novas escolas na ciência, na filosofia e na literatura».
(4) A.U.C., Documentação Avulsa. 
arejamento na vida política nacional e como palco frequente dessas lutas apareciam os Gerais e o Pátio da Universidade. De uma reunião tida em 29 de Janeiro de 1898 surgiram dois grupos: o grupo republicano que se dirigiria ao Porto em comemoração do seu 31 de Janeiro e o que, fiel ao rei, proclamava a adesão às instituições vigentes e o seu respeitoso acatamento pela dinastia reinante $(5)$.

Em 6 de Fevereiro tentam os estudantes levar a cabo uma homenagem a Mouzinho de Albuquerque no Teatro Circo e no Salão da Trindade, homenagem essa logo sufocada pela autoridade administrativa, o que originou graves conflitos. A comissão republicana que chegava do Porto na altura, fora também alvo de severa repressão. Como consequência destes actos, o reitor, Doutor António Augusto da Costa Simões, pede a demissão sendo nomeado em sua substituição o Doutor Manuel Pereira Dias (6).

(5) Oficio dirigido ao Ministro do Reino pelo então Reitor Augusto da Costa Simóes (Oficios da Reitoria, 1899-1900, fl. 18v.).

$\left.{ }^{(}\right)$Foram reitores da Universidade a partir da Reforma Pombalina até ao presente: D. Francisco de Lemos de Faria Pereira Coutinho (1770-1779 e 1799-1821), D. José Francisco Miguel António de Mendonça (1780-1785), D. Francisco Rafael de Castro (1786-1799), D. Francisco de S. Luís (1821-1823), D. Diogo de Castro do Rio Furtado de Mendonça (1823-1827), Sebastião Correia de Sá (Conde de Terena) (1841-1848), José Machado de Abreu (1850-1853), Basilio Alberto de Sousa Pinto (Visconde de S. Jerónimo) (1859-1863), Vicente Ferrer de Neto Paiva (1863-1864), António Luís de Seabra (Visconde de Seabra) (1866-1868), Júlio Máximo de Oliveira Pimentel (Visconde de Vila Maior) (1869-1884), Adriano de Abreu Cardoso Machado (1886-1890), António dos Santos Viegas (1890-1892 e 1906-1907), António Augusto da Costa Simões (1892-1898), Manuel Pereira Dias (1898-1906), D. João de Alarcão Velasques Sarmento Osório (1907), António das Neves Oliveira e Sousa (1907-1908), Alexandre Cabral Pais do Amaral (1908-1910), Manuel de Arriaga Brum da Silveira (1910-1911), Daniel Ferreira de Matos Júnior (1911), Joaquim Mendes dos Remédios (1911-1913 e 1918-1919), Guilherme Alves Moreira (1913-1915), Arnaldo Mendes Norton de Matos (1916-1918), Joaquim José Coelho de Carvalho (1919), Filomeno da Câmara de Melo Cabral (1919-1921), António Luís Gomes (1921-1924), Francisco Pinto da Cunha Leal (1924-1925), Henrique Jardim de Vilhena (1925-1926), Fernando Duarte Silva de Almeida Ribeiro (1926-1927), Domingos Fezas Vital (1927-1930), João Duarte de Oliveira (1931-1939), António Luís de Morais Sarmento (1939-1941), Maximino José de Morais Correia (1943-1960), Guilherme Braga da Cruz (1961-1963), António Jorge Andrade de Gouveia (1963-1970), José Gouveia Monteiro (1970-1971), João Manuel Cotelo Neiva (1971-1974), José Joaquim Teixeira Ribeiro (1974), António Arruda Ferrer Correia (1975-1982), Rui Nogueira Lobo Alarcão e Silva (1982....). 
Por portaria de 3 de Janeiro de 1899, assinada por José Luciano de Castro $\left({ }^{7}\right)$, teria a Universidade de Coimbra de apresentar pareceres sobre a reforma do Ensino Superior de acordo com os seguintes pontos:

1 - Organização das Faculdades que devem compor este importante estabelecimento no intuito não só de dar a necessária uniformidade aos métodos no sistema geral do ensino de cada uma, mas também tendo em vista a instituição de quaisquer cursos especiais que se julguem convenientes aos interesses do Estado.

2 - Duração do ensino em cada ano lectivo por modo que se concilie o maior aproveitamento dos alunos com o tempo necessário para as provas finais do ano.

3 - Sistema que convenha adoptar-se no juízo das provas académicas durante o ano lectivo, no julgamento final dos alunos e na graduação do mérito de cada um.

4 - Professorado: sua organização, deveres e obrigações, provimento, prerrogativas e vencimentos.

5 - Doutoramento: em que condições e mediante que provas deverá ser conferido.

6 - Regime escolar e disciplinar a que devem estar sujeitos os alunos durante os seus cursos.

7 - Penalidades que devem estabelecer-se contra as faltas dos lentes e empregados da Universidade no exercício das respectivas funções.

Reunidas as Faculdades surgiu assim uma comissão destinada a emitir os seus pareceres sobre a tão almejada Reforma.

Por ofício de 4 de Março de 1899 foi enviada à Direcção Geral de Instrução Pública o nome dos lentes que, por Faculdades, formavam a respectiva comissão $\left(^{8}\right)$ :

(7) José Luciano de Castro, fazendo parte do Novo Partido Progressista, entra no governo em Junho de 1879. Considerado responsável pelo «Ultimatum», este governo demite-se. Em 1897 José Luciano de Castro entra novamente no governo até 1900, altura em que os Progressistas cedem o lugar a Hintze Ribeiro e aos Regeneradores. Em 1904 está de novo no poder até Março de 1906. Sucedeu-lhe Hintze com um ministério regenerador que não esteve no poder mais de cem dias Luciano de Castro nasceu em Oliveirinha, em 14 de Dezembro de 1834, e faleceu em Anadia a 9 de Marco de 1914. Formou-se em Direito pela Universidade de Coimbra. Colaborou em vários jornais e foi estadista notável, tendo desempenhado cargos importantes. Dotado de grande erudição e inteligência, escreveu trabalhos diversos a fundou $O$ Direito, importante revista de jurisprudência. Deixou uma biblioteca notabilíssima legada em 1938 por suas filhas às bibliotecas municipais de Anadia e Aveiro.

${ }^{8}$ A.U.C., Legislação Académica (Documentação Avulsa). 


\section{Ideal Republicano}

Teologia -

Luís Maria Silva Ramos, professor catedrático

Manuel de Azevedo Araújo e Gama, professor catedrático

Joaquim Mendes dos Remédios, professor substituto

Direito José Pereira Paiva e Pita, professor catedrático

António Lopes Guimarães Pedrosa, professor catedrático

Abel Pereira de Andrade, professor substituto

Medicina - Costa Alemão, professor catedrático

Augusto Rocha, professor catedrático

Serras e Silva, professor substituto

Matemática - Augusto de Arzila Fonseca, professor catedrático

Luciano António Pereira da Silva, professor substituto

Sidónio Pais, professor substituto

Filosofia - Bernardino Machado, professor catedrático Gonçalves Guimarães, professor catedrático

Teixeira Bastos, professor catedrático

A reforma universitária era uma preocupação constante quer para alunos, quer para professores. Nos seus centenários (de referir o centenário da Sebenta nos dias 29 e 30 de Abril de 1899) os estudantes não deixavam de fazer uma charge à Universidade anquilosada que possuiam. Os mestres, por conta própria, procuravam acompanhar o espantoso progresso que se ia desenrolando na Europa no campo do saber. Já em 1892, Bernardino Machado presidia ao Congresso Pedagógico Hispano-Português em Madrid, estabelecendo estreitas relações com a Institución Libre de Enseñanza onde colaboravam os mais progressistas pedagogos de Espanha, em particular o seu fundador D. Francisco Giner de los Rios. Participa activamente nos Congressos do Professorado Primário (1892 e 1897), sendo o redactor das respectivas conclusões que não deixam de ser um manancial de informações sobre as reivindicações profissionais e pedagógicas dos docentes daquele grau de ensino. Podemos considerar o Congresso de 1892 a primeira tentativa de criação de uma 


\section{Revoltas e Revoluções}

federação de sindicatos de docentes a nível nacional. Criou a cadeira de Antropologia Física inaugurando um novo estilo de ensino em que abolia a aula centrada no professor para dar lugar aos trabalhos de tipo seminário em que o aluno, em estreita convivência e colaboração com o mestre, se ia iniciando na pesquisa científica. Em Janeiro de 1900 foi-lhe concedida licença para, aos domingos e em hora compatível com o serviço e trabalho do Museu de Zoologia, proferir um Curso Livre de Pedagogia, frequentado por alunos de todas as Faculdades $\left({ }^{9}\right)$. Logo na lição inaugural se refere ao facto de em Portugal todos falarem de ensino, vários o professarem mas poucos saberem o que é. Ensinam-se muitas coisas mas ainda não se ensina a ensinar. Estabelece a diferença entre Educação e Ensino dizendo: «Quando fazemos arte, indústria ou ciência esforçando-nos o mais possível pelo desenvolvimento das nossas faculdades, pela nossa instrução, fazemos educação; quando o fazemos pelos outros, esforçando-nos sobretudo porque eles desenvolvam as suas faculdades, porque eles se eduquem, fazemos ensino».

Pretendendo uma socialização do ensino, refere-se à necessidade de uma Universidade que dirija os seus caminhos na direcção dos mais infelizes. Que leve o seu ensino aos bairros operários, aos campos e às minas - «o ensino é uma função social, é obra de assistência, de dedicação, de sacrifício. É aquilo que não querem todos os adversários do socialismo, todos os individualistas».

Refere-se também à habilitação profissional, necessária para todo o ensino e que de momento é uma lacuna que se tenta preencher. Considera que a pedagogia apenas se esboça nas Escolas Normais Primárias e embora a lei exija provas pedagógicas aos candidatos ao magistério secundário não há ainda onde eles se preparem para as dar. «Ninguém se habilita para o ensino que não comece por o servir modestamente praticando como simples ajudante com mestres abalizados. E para ascender a professor do Ensino Superior, ninguém devia deixar de percorrer a escala desde o Ensino Primário» $\left({ }^{10}\right)$.

As suas reflexões sobre o ensino, visivelmente actuais inserem-se nos movimentos da Escola Nova: Democratização do acesso ao ensino e, consequentemente, um regime social e económico de carácter igualitário são os pontos essenciais do legado pedagógico de Bernardino Machado. Lutando por uma

1899-1900, fl. 99.

(9) A.U.C., Ofícios da Reitoria da Universidade de Coimbra,

(10) Bernardino Machado, Curso de Pedagogia, Coimbra, Imprensa da Universidade, 1900. 
Escola Nova ele é acompanhado por outros professores que também sentem a urgência de uma Reforma Universitária. Em 12 de Outubro de 1900 o Doutor António de Assis Teixeira de Magalhães, lente catedrático da Faculdade de Direito, pede ao Rei 30 dias de licença para ir estudar a organização do ensino superior em alguns países do Estrangeiro $\mathrm{O}^{1}$ ).

Internamente a vida universitária era de grande instabilidade. Às questões entre professores (12) sucediam-se as lutas entre estudantes, e o governo tentando uma acalmia da situação, envia às Faculdades as bases de uma reforma universitária (21 e 23 de Fevereiro de 1900) cujo projecto pretende submeter ao Parlamento. O vice-reitor, Doutor António José Gonçalves Guimarães, dirigindo-se ao Director Geral da Instrução Pública refere-se ao agrado com que a Universidade recebeu estas bases e espera que da sua próxima conversão em lei resultem decididas vantagens para o ensino, embora as circunstâncias precárias do tesouro não permitam os melhoramentos necessários (1S). Logo que os pareceres das Faculdades são enviados, é apresentada ao Parlamento a Proposta de Lei n. ${ }^{\circ}$ 42-L (14) datada de 15 de Abril de 1901. Esta proposta restaura o regime de opositores que apareceu pela primeira vez nos Estatutos da Universidade de Coimbra de $1772\left({ }^{15}\right)$. Ensina ainda a doutrina de que os compêndios escritos, especialmente para as cadeiras da Universidade, teses e dissertações, actos grandes e concursos, sejam obrigatoriamente impressos na Universidade.

Referindo-se à Faculdade de Teologia, considera que as bases da sua reforma são determinadas pela nova fase que revestem os estudos teológicos modernos. Os graves problemas da teologia dogmática não podem ser conscienciosamente estudados sem os conhecimentos ministrados na Antropologia e Geologia (cadeiras de Filosofia). A aprovação na língua grega e hebraica fica sendo habilitação necessária para a matrícula no $4 .^{\circ}$ ano pois os estudos bíblicos (Isagoge Geral, Arqueologia, Isagoge Especial, Hermenêutica e Exegese) não podem ser professados sem notícia exacta das línguas gregas e hebraicas.

(") A.U.C., Ofícios da Reitoria da Universidade de Coimbra, 1900-1902, fl. 19.

(12) De referir a questão entre os Professores da Faculdade de Direito, Guilherme Alves Moreira, José Maria Joaquim Tavares e Afonso Costa, conhecida por Conflicto Pessoal. Vid. Conflicto Pessoal, Coimbra, Thypographia França Amado, 1900; e os jornais O Norte, de 10 de Fevereiro de 1900 e Resistência, de 11 e 22 de Fevereiro de 1900.

\section{0-1902, fl. $68 \mathrm{~V}$. \\ (14) Diário do Governo, n. ${ }^{\circ}$ 84, de 17 de Abril de 1901.}

(*)" A.U.C., Oficios da Reitoria da Universidade de Coimbra,

(15) Estatutos da Universidade, liv. II, tit. 12. ${ }^{\circ}$, n..$^{\circ} 1$ ss., p. 564. 
Em relação à reforma dos estudos da Faculdade de Direito é proposta como primeira cadeira da Faculdade a Sociologia Geral e Filosofia do Direito. Mantém-se o estudo do Direito Romano, o Direito Eclesiástico Público Comum e o Direito Eclesiástico Privado Comum. Considerando que o ensino das Faculdades de Direito não pode deixar de ser teórico e prático ao mesmo tempo, porque só a prática pode esclarecer e dar vida aos princípios científicos e só a teoria pode tornar consciente, racional e verdadeiramente profícua a prática, a proposta apresenta a criação da cadeira de Prática Extra-Judicial, à semelhança dos seminários jurídicos que as Faculdades alemãs possuem ao lado dos seus cursos, com a missão de completar o ensino teórico.

Dada a extensão do domínio colonial, a dificuldade de o administrar convenientemente e a vizinhança de colónias modelarmente geridas, tornava-se urgente também a proposta de criação de uma cadeira de Administração Colonial, necessária aos funcionários ultramarinos que não eram obrigados a qualquer habilitação profissional. Dado que a Inglaterra possuia diversos institutos: India audit office, índia forest service, India office, India civil service, e a França a L'Ecole Coloniale d'Etat, não era portanto de admirar a incompetência dos nossos funcionários em comparação com os das outras nações coloniais e por conseguinte a necessidade de uma cadeira de tal natureza.

Apresentada esta proposta em 15 de Abril de 1901, da qual referimos algumas questões, os professores universitários continuam a reclamar a urgência da reforma e em Claustro Pleno de 30 de Novembro de 1901 apresentam a seguinte proposta: «Propomos que seja nomeada uma comissão de 5 membros, sendo um por cada Faculdade com o fim de se empenhar com o governo, em nome da Universidade para que seja decretada antes do fim de Dezembro a reforma da Universidade na parte científica (organização dos estudos) e nos pontos disciplinares que forem submetidos à apreciação dos conselhos académicos» $\left({ }^{16}\right)$. Assim no Diário do Governo n. ${ }^{\circ} 294$ de 28 de Dezembro de 1901, as bases da Reforma Universitária passaram a Decreto-Lei.

Em 10 de Abril de 1902, o Corpo Docente da Universidade, reunido em Claustro Pleno, dirige-se à Câmara dos Dignos Pares do Reino. Pretende que seja restabelecida a melhoria do terço de ordenado aos professores do Ensino Superior com vinte anos de bom e efectivo serviço e estabelece a comparação

(1C) A.U.C., Assentos dos Claustros, 1856-1910, foi. 95 v. 


\section{Ideal Republicano}

com os magistrados judiciais, onde não encontrando justificação, atestam uma flagrante desigualdade $\left({ }^{17}\right)$ :

Juízes do SupremoTribunalde Justiça, ordenado 2:000\$000 reis

Terço

$666 \$ 666 »$

Juízes das Relações, ordenado

$1: 600 \$ 000 »$

Terço

$533 \$ 333 \gg$

Professores Catedráticos da Universidade, ordenado $800 \$ 000$ »

Terço

$266 \$ 666 \gg$

Professores propriet, dos outros estabelecimentos 700\$G00 »

Terço

$233 \$ 333 »$

Enquanto os professores apresentam as suas reivindicações, os estudantes lutam também pela liberdade de Associação contra a autoridade administrativa que lhes impede de se reunirem na extinta igreja da Trindade onde estava instalado o ginásio da Associação Académica. Reunem-se no Largo da Feira, querem a greve e manifestam-se contra o Convénio (18). São os estudantes João dos Santos Monteiro, Domingos Rodrigues da Silva Pepulim, Fausto Quadros e Francisco Xavier Valladares, que dirigem todo este movimento $\left({ }^{19}\right)$.

Os Reitores recorreram por várias vezes à suspensão dos trabalhos escolares e intimam os alunos da Universidade a deixarem Coimbra no prazo de 24 horas:

- Edital de 30 de Abril de 1902 - Encerramento da Universidade.

— Edital de 22 de Maio de 1902 - Abertura e recomeço das aulas.

A consciência republicana ia-se acentuando de dia para dia e para a deter surgia a ditadura de João Franco, mas como à violência responde também a violência, em Março de 1903, o terreiro da Universidade era invadido por centenas de "paisanos» que pretendiam o encerramento da Universidade, o que leva o Reitor a enviar um ofício ao Conselheiro Governador Civil do Distrito de Coimbra pedindo providências contra os tumultos populares e pedindo as forças de cavalaria para a Porta Férrea $\left({ }^{20}\right)$.

(17) A.U.C., Documentação Avulsa.

(18) Vide Jornal Resistência, Coimbra, 13 de Abril de 1902, artigo «Contra o Convénio - Attitude d'Academia - Reunião Importante».

(19) A.U.C., Processos da Polícia Académica.

C) A.U.C., Oficios da Reitoria da Universidade de Coimbra,

1902-1903, foi. 148. 


\section{Revoltas e Revoluções}

Encerra a Universidade através de um edital onde proíbe o uso do vestuário académico e em 20 de Abril abre novamente a Universidade. Toda esta instabilidade não deixa de ser o reflexo da vida política nacional e também a consciencialização da urgente necessidade de uma Universidade actual que respondesse às aspirações de todos. Daí as Orações de Sapiência proferidas na Sala dos Capelos pela abertura das aulas.

Bernardino Machado em 16 de Outubro de 1904 apresenta a Oração Inaugural do ano lectivo subordinada ao título: «A Universidade e a Nação» (21). Refere-se logo de início aos governos reaccionários que se seguiram aos governos liberais e à acção demolidora que exerceram sobre a instrução, acção que se traduziu na extinção do ministério da instrução pública, no desaparecimento da representação parlamentar dos estabelecimentos de ensino, na centralização do ensino primário, monopolização do ensino secundário e cerceamento das regalias do ensino superior chegando a fazerem-se «reformas» da Universidade sem consulta do seu magistério.

Considera que é urgente apelar para uma educação salvadora, a educação liberal, assente na liberdade, na busca da verdade não para a monopolizar mas para com ela enriquecer um património comum. A Universidade tem por missão produzir ideias e não consumi-las. Deve ser uma oficina onde professores e discípulos num trabalho comum desçam da omnipotência das suas cátedras e se dirijam por toda a parte, às cidades e aos campos, às fábricas e às minas, instruindo e ensinando o povo num serviço franco e desinteressado. Alude assim à socialização da Escola, tarefa sem dúvida difícil em que se devem irmanar mestres e discípulos empenhados na formação de uma Universidade Nova, tarefa tanto mais árdua quanto pairam sobre as suas cabeças o terror dos castigos, traduzido na expulsão e perda de anos para os alunos e na punição dos lentes pelas suas opiniões democráticas.

Bernardino Machado termina referindo-se à penúria que reina por todos os departamentos universitários como reflexo da penúria da nação. A imagem da Escola não é mais do que a imagem decadente da Pátria. Esta oração, logo contestada pelo Presidente da sessão, Doutor Avelino César Augusto Maria Calisto, lente de Direito, que considerou inoportunas as considerações feitas, teve no entanto grandes repercussões no país, em especial nos centros republicanos.

Em 1907, Sobral Cid, lente catedrático de Medicina, na sua Oração de Sapiência de 16 de Outubro, estabelece um para-

(21) A.U.C., Annuário da Universidade, vol. XCVIII-XCIX 1907-1908, pp. XXXVII-LXVI. 


\section{Ideal Republicano}

lelismo entre a Universidade Portuguesa e as Inglesa, Alemã e Francesa, referindo-se à necessidade de uma autêntica reforma, que leve a Universidade a desempenhar a tríplice função de preparar o profissional para a carreira, o cidadão para o Estado e o homem para a Ciência.

Refere-se àqueles que, impressionados pela existência secular da Universidade e sobrevivência dos símbolos da sua vida tradicional e corporativa, enfermam do erro de a isso atribuírem os defeitos do seu ensino e o vício da sua organização. Considera que a Universidade Portuguesa não é uma sobrevivência histórica e pedagógica, destoante da sua época e do seu tempo, mas no estado actual em que se encontra não é mais do que fruto do constitucionalismo. Organizada pelos estadistas constitucionais, estava subordinada ao Estado quer sob o ponto de vista administrativo quer pedagógico. Sem autonomia e liberdade, preparava apenas para o exercício profissional, divorciada da livre investigação e da elaboração científica.

$\mathrm{O}$ Estado não reconhecia às Faculdades autoridade e competência para ordenarem livremente o curso dos seus estudos e reservava para si próprio até o direito de aprovar os livros escolhidos. A Universidade não era mais do que o resultado de um Estado autoritário e centralizador que, colocando a instrução sob tutela, tornava as escolas verdadeiras fábricas de diplomados donde havia de sair a grande parte dos funcionários públicos e os dirigentes políticos da Nação.

No entanto, Sobral Cid diz que apesar de toda esta centralização estatal, o espírito científico penetra em várias Faculdades graças ao esforço dos seus mestres. Exemplifica com a Faculdade de Medicina, onde por iniciativa do seu professorado se transformou em poucos anos o ensino oral e expositivo num ensino técnico e demonstrado. Considera que a nova era da Faculdade de Medicina data de 1866 como consequência da visita aos centros universitários alemães feita pelo Doutor António Costa Simões onde a Medicina por influência de Miiller, Helmotz e outros, se emancipava das velhas especulações filosóficas e se lançava na investigação científica.

Costa Simões funda o Laboratório de Histologia não só para exercícios práticos e demonstrações do curso, mas também para a livre investigação científica; Augusto Rocha em 1882 funda o Gabinete de Bacteriologia; Sousa Refoios e Daniel de Matos lançam-se na criação da grande cirurgia ginecológica e obstétrica. São no fundo iniciativas dos professores e nunca obra do Estado que até por vezes tolhia a sua realização. Lembra o acontecido com o Laboratório de Bacteriologia, estabelecido com uma subvenção de $70 \$ 000$ reis dados pela Faculdade e que em 1890 ainda não tinha instalação própria e só em 1901, 


\section{Revoltas e Revoluções}

dezanove anos depois da sua fundação, fora oficialmente reconhecido e dotado no orçamento.

Considera que apesar de acompanharmos o movimento científico europeu, continuamos ainda muito limitados. Verificamos, reproduzimos, mas nada criamos. O nosso ensino continua a ser mera imitação pois a Universidade encontra-se impotente para a criação científica. Os trabalhos de investigação que esporadicamente aparecem são obras de autodidactas, investigações extra-docentes, como a obra histórica de Gama Barros, a obra filológica de Adolfo Coelho, a obra monumental de Teófilo Braga e muitas outras. Urge começar em Portugal a regeneração do ensino superior, dando à Universidade liberdade e independência do Estado; a professores e alunos liberdade de ensino ou de aprender dentro da Universidade tornando possível o uso dessa liberdade pela instituição e desenvolvimento de Bibliotecas, Seminários, Institutos e Clínicas, liberal e generosamente dotados. Em qualquer reforma que se faça, diz Sobral Cid, é de ter em conta sempre a autonomia e independência da Universidade, simbolizada pela eleição do Reitor. «O reitor eleito é o símbolo visível da independência corporativa da Universidade».

Critica os exames que em Portugal não são mais do que a fiscalização anual pela qual um sistema pedagógico que se impõe pela autoridade e se baseia na desconfiança verifica o aproveitamento do aluno. Considera-os um empecilho e um obstáculo ao acesso da livre actividade científica. Alude ao sistema de exames alemão como um exemplo a seguir.

Termina a Oração de Sapiência fazendo um estudo retrospectivo sobre a Universidade Portuguesa desde o «Studium Generale» (1288), passando pela Universidade Joanina no século XVI, à Universidade Pombalina ou reformada em 1772 e termina na Universidade do Constitucionalismo. Considera o século XVI como o período áureo da vida universitária portuguesa, prestígio que alcançou com o seu fundador intelectual Diogo de Gouveia. Este insigne pedagogo fez os seus estudos em Paris, doutorou-se e professou na Sorbonne e alcançou celebridade como Principal do Colégio de Santa Bárbara. Durante o seu principalato, este Colégio com os seus cinquenta bolseiros de El-Rei, foi como que um seminário pedagógico do professorado português. Considera ainda que qualquer reforma universitária terá de ter origem num fundador intelectual. A Universidade Joanina teve Diogo de Gouveia, a Universidade Pombalina teve Ribeiro Sanches que, do seu exílio em Paris, dirigia a Pedro da Costa de Almeida Salema, as Cartas sobre a educação da mocidade, onde o Marquês se inspirou para a cria- 


\section{Ideal Republicano}

ção do Colégio dos Nobres. São essas cartas talvez uma primeira sugestão pedagógica para a reforma de 1772 .

Ribeiro Sanches viveu por muito tempo no ambiente do enciclopedismo. Era dotado de uma independência mental e livre crítica que o fazia ser mal visto em Portugal e na Corte; no entanto o Marquês de Pombal que o sabia mas não queria perder os seus conselhos e indicações, apresentou com o pseudónimo João Sacheti as memórias e relatórios que Ribeiro Sanches enviara de Paris para a elaboração dos novos Estatutos. Quer uma quer outra Universidade conseguiram encaminhar a sociedade portuguesa a par das nações mais cultas da Europa. À Universidade do Constitucionalismo faltou-lhe o seu Fundador Intelectual e por isso não conseguiu desempenhar uma missão superior na vida da Nação. Como solução, Sobral Cid diz que a Universidade Portuguesa para se regenerar terá de seguir o exemplo das Universidades Alemãs, assentando na autonomia corporativa e na livre investigação científica para caminhar em paralelo com as universidades europeias $\left({ }^{22}\right)$.

Este ano, inaugurado por Sobral Cid, ficou marcado na Academia Coimbrã. O candidato a doutor José Eugênio Ferreira, reprovado por unanimidade no acto de conclusões magnas de doutoramento, deu origem a um protesto geral da Academia traduzido na grave académica e na demissão apresentada por Bernardino Machado que solidarizando-se com os estudantes, abandonou a sua cátedra, atitude que originou várias manifestações do Partido Republicano, nomeadamente uma homenagem nacional, presidida por Teófilo Braga (23). A própria Faculdade de Filosofia reuniu-se para mostrar quanto sentia a sua retirada e ao mesmo tempo agradecer os relevantes serviços prestados à Faculdade $\left({ }^{24}\right)$.

Em 1908, Sidónio Pais, na sua Oração de Sapiência, proferida a 16 de Outubro, escolheu para tema o ensino universitário que considera uma questão gravíssima, dado que paira sobre ele grande descrédito e até hostilidade. A Universidade de Coimbra, a única existente no país, está a perder o seu antigo prestígio e começa a ser olhada como uma instituição anacrónica e perniciosa. Sidónio Pais encontra como defeitos fundamentais na Universidade Coimbrã a subsistência das velhas fórmulas da sua primitiva estrutura religiosa e clerical. As obrigações de carácter religioso são impostas quer a pro-

(22) A.U.C., Annuário da Universidade de Coimbra, vol. CII 1903-1905, pp. XXIX-XLIX.

(23) Vide Alberto Xavier, História da Greve Académica de 1907. Coimbra, 1962.

(24) A.U.C., Actas da Faculdade de Filosofia, 19 de Maio de 1907. 
fessores quer a alunos: os estudantes têm de fazer um juramento religioso no acto da matrícula e os professores terão de o fazer no início do ano lectivo. Antes do exame o aluno reza uma oração latina em que invoca o auxílio de Deus, o grau de licenciado é conferido na capela e o de doutor é precedido de Missa com um ceremonial verdadeiramente ritual. Mantém-se o traje clerical de estudantes e lentes, embora seja incessante a sua contestação.

Outro dos defeitos é a anulação da iniciativa do aluno, defeito aliás de que enferma todo o ensino em Portugal. Começando pela Escola Primária caracterizada por um formalismo rígido e deformante onde a ordem é perfeita mas o cérebro se atrofia, passando pelo liceu onde o melhor professor é aquele que explica melhor e o melhor aluno é aquele que melhor decora a exposição do professor, e terminando na Universidade, onde se faz um curso sem se resolver um problema, sem se ter feito um único esforço pessoal de investigação verificamos que todo o ensino leva à inacção: ouvir o professor, colher apontamentos e compilá-los!

Sidónio Pais considera que cada professor terá de modificar totalmente os seus processos de ensino e critérios de julgamento. Deve criar ao aluno o gosto pelo trabalho, desenvolver-lhe o espírito de iniciativa, a curiosidade de descobrir e a originalidade. $O$ professor trabalha com o aluno, está em contacto com ele todo o ano, avalia-o pelos trabalhos feitos e pelo esforço dispendido e o exame tornar-se-á uma inutilidade.

A Universidade alargará a sua esfera de acção. Deixará de ser um privilégio para aqueles que têm dinheiro mas estender-se-á a todas as camadas da população. Refere-se assim à extensão universitária que já há anos se está realizando em todos os países universitários e termina dizendo que a Universidade de Coimbra tem de tomar uma decisão: ou é pelo passado, pelo espírito de rotina e tem de morrer; ou é pelo progresso, pelo epírito científico e pela liberdade e então tem de sofrer uma transformação radical que a leve a tornar-se no principal centro de educação portuguesa $\left({ }^{25}\right)$.

Em 25 de Maio de 1908 reuniu-se o Conselho de Decanos sob a presidência do então reitor Alexandre Ferreira Cabral Paes do Amaral. Tinha por finalidade resolver na forma dos Estatutos sobre o pedido a El-Rei para que se declarasse Protector da Universidade. Era a primeira vez que desde 1902 se fazia uma reunião de Claustro Pleno ( ${ }^{62}$ ). Aprovada a acta da sessão anterior,

(") Annuário da Universidade de Coimbra, vol. CIII-CIV, 1908-1910, pp. XLIII-LIV.

(M) A.U.C., Assentos dos Claustros, 1856-1910, foi. 101. 
Daniel de Matos, lente de Medicina, foi o primeiro decano a manifestar-se declarando que apoiaria o pedido do Protectorado Real se a comissão encarregada nesse sentido desse a conhecer ao Monarca as precárias condições da Universidade e não fosse com o intuito de apenas fazer meras afirmações de carácter político; que não fosse apenas um acto de lealismo monárquico mas que aproveitassem para dizer ao Rei que governasse segundo a Lei, com espírito moderno e, sobretudo, para chamar a sua atenção a favor dos legítimos interesses da Universidade. Manifestou-se de seguida Sobral Cid, considerando que não tinha qualquer simpatia pela ideia do Protectorado Real, cuja significação era a da dependência da Universidade pelo poder central. Apresenta as seguintes propostas ao Conselho:

\section{Proposta A:}

«1 - Considerando que é próprio das Universidades antigas e modernas elegerem livremente o Reitor $\mathrm{e}$ as autoridades académicas as quais exercem o governo universitário por delegação da corporação soberana.

2 - Considerando que a Universidade de Coimbra possuia orginariamente esse direito e o exerceu livremente desde a fundação do Estudo Geral em Lisboa até à instituição do Protectorado Real no reinado de D. Manuel I.

3 - Considerando que sobre o regimen do Protectorado os Reis Protectores usurpando os direitos e privilégios corporativos, se arrogavam a escolha e nomeação do Reitor, sem audiência do Claustro e contra a letra expressa dos Estatutos Manuelinos e seguintes, convertendo-se por fim o abuso em lei.

4 - Considerando que no vigente regime constitucional (não só) foi sancionada tal disposição, sendo o Reitor nomeado e demitido livremente pelo poder executivo (mas se agravou por se considerar o Reitorado como um cargo de confiança política, o que é vexatório e anti-universitário).

5 - Considerando que em todos os Estados modernos e modernas Universidades, o Reitor não é um funcionário do Estado, delegado do poder Central, mas o chefe eleito da corporação e o símbolo visível da independência corporativa.

6 - Considerando ainda que nas Universidades escandinavas e escocesas os estudantes e nações tomam parte na eleição e que efectivamente a universidade moderna é como uma universidade medieval, uma corporação de professores e estudantes - os Professores da Universidade, reunidos em Claustro Pleno na noite de 25 de Maio de 1908 no uso das limitadas funções que lhe restam dos seus antigos e legítimos poderes e 


\section{Revoltas e Revoluções}

atribuições, cônscios dos seus direitos tradicionais e em nome das suas aspirações de reconstituição universitária reclamam perante o Estado e a Nação o direito de eleger as suas autoridades académicas e de por si próprios governarem a corporação».

\section{Proposta B:}

«1 - Considerando que sempre e em todos os Estados salvo infelizes excepçÕes, a Universidade foi no seio da nação uma pessoa moral com capacidade jurídica para receber por herança, legado ou doação, adquirir e gerir os próprios bens.

2 - Considerando que assim foi originariamente a Universidade de Coimbra senhora de um opulento património progressivamente enriquecido, que ela própria administrou até ao estabelecimento do regimen constitucional vigente, o qual, a título de extinguir os privilégios do antigo regime, destruiu a autonomia económica da Universidade encorporando os seus bens, rendas e acções nos próprios nacionais.

3 - Atendendo a que no mesmo período histórico todos os modernos Estados, excepto a França e a Espanha, respeitaram a autonomia económica das Universidades, considerando-a como uma condição inerente à Instituição e favorável ao seu d esenvolvimento.

4 - Considerando que a actual dotação da Universidade é manifestamente insuficiente para satisfazer as necessidades do seu ensino moderno e da investigação científica, enquanto outras Instituições do Estado de carácter regressivo, são largamente dotadas.

5 - Considerando que as representações das Faculdades Académicas e as iniciativas do professorado no sentido de desenvolver e aperfeiçoar os meios de ensino são olvidadas ou tardias e insuficientemente atendidas, como se o Estado fosse o primeiro a desejar o atraso do ensino superior.

Os Professores da Universidade, reunidos em Claustro Pleno na noite de 25 de Maio de 1908, no uso dos limitados direitos que restam dos seus legítimos poderes e atribuições reclamam do Estado e da Nação:

1. ${ }^{\circ}$ - A reconstituição do património universitário, arrecadando a Universidade a totalidade dos próprios rendimentos.

2. $\quad{ }^{\circ}$ - As dotações suplementares necessárias para desenvolver rápida e intensivamente os seus estabelecimentos de ensino de harmonia com os primaciais interesses do país. 


\section{Ideal Republicano}

$3 .^{\circ}$ - O reconhecimento da capacidade de administrar livremente o patrimonio corporativo e as dotações do Estado, prestando anualmente contas à nação.

\section{Proposta C:}

«1 - Considerando que a função primacial e característica do ensino superior é a criação contínua da ciência pela aplicação dos métodos de investigação científica, isto é, a descoberta da verdade e a sua aplicação incessante em benefício da vida individual e colectiva, a conquista do bem.

2 - Considerando que a Universidade deve ter por objecto o estudo das ciências da natureza, das Letras (ciências do Homem) e das ciências aplicadas, como meio do ensino dos métodos de investigação científica, por fim a formação de investigadores independentes, de profissionais instruídos, e a difusão do espírito científico através de todas as classes da nação.

3 - Considerando que a Universidade Pombalina foi organizada nestas bases, especialmente pelo que respeita às 3 Faculdades Naturais as quais foram constituídas não só como corpos de ensino mas também como academias de sábios, com o fim de adiantar as ciências consignando-se que os Professores deviam ser Mestres-Inventores como nas modernas universidades.

4 - Considerando que as reformas efectuadas sob o regime constitucional, colocando a Universidade sob a tutela do Estado, como uma dependência burocrática do Ministério do Reino, e organizando as Faculdades como Escolas Profissionais ou preparatórios superiores, falsearam a missão da Universidade e a têm impedido de desempenhar o papel que lhe devia pertencer na evolução da sociedade portuguesa.

5 - Considerando que o Estado não tem tido sequer a consciência da necessidade da existência do verdadeiro ensino superior, e que é absolutamente incompetente para empreender úteis reformas pedagógicas, como demonstra o estado actual de todos os ramos da instrução pública.

6 - Considerando que as verdadeiras reformas do ensino do século XVI e do século XVIII foram o produto da élite da nação, os professores da Universidade, reunidos em Claustro Pleno na noite de 25 de Maio de 1908, propoem-se convocar uma grande assembleia pedagógica, em que tomem parte o corpo docente de todos os estabelecimentos de ensino superior e os intelectuais portugueses».

Em face das propostas de Sobral Cid, depois de grande polémica levantada, o Claustro Pleno considera que não po- 


\section{Revoltas e Revoluções}

dendo naquele momento discuti-las e apreciá-las, deixava ao Reitor o cuidado de lhe dar o devido seguimento.

Outros professores se manifestaram como Sidónio Pais que votou contra o Protectorado Real em virtude de o considerar como uma praxe antiquada que lhe lembrava a homenagem do vassalo ao seu senhor. Por outro lado, entendia que a Universidade devia observar sempre e em tudo completa neutralidade política.

Finalmente foi aprovada a proposta do Doutor Sousa Gomes: «Proponho que o Prelado com o Conselho dos Decanos aos quais possa agregar-se o maior número de professores que queiram ir a Lisboa, peçam a sua Magestade El-Rei que se declare protector da Universidade na forma dos Estatutos, e que nessa ocasião, o Senhor Reitor, apresentando a El-Rei os votos da Universidade pela prosperidade do seu reinado, solicite a sua coadjuvação eficaz para a realização das reformas que a mesma Universidade reputa necessárias e urgentes» $\left({ }^{27}\right)$.

É constante como se vê, o ataque às prerrogativas e tendências conservadoras da Universidade.

Em 1909, no alvorecer da República, Eusébio Tamagnini de Mattos Encarnação, lente da Faculdade de Filosofia, embora mais moderado começa a sua Oração de Sapiência por fazer uma análise da situação do país que considera miserável e bastante difícil. Debruça-se sobre a crise da agricultura, cuja origem está não só na ausência dos conhecimentos científicos indispensáveis à cultura da terra por parte dos lavradores, como também à dificuldade de colocação dos produtos no Estrangeiro. No plano industrial basta analisar a situação precária em que se encontram as fiações de algodão e duma maneira geral toda a indústria portuguesa. No plano comercial são constantes as firmas que entram em falência; o movimento literário, científico e artístico é insignificante, não se registam descobertas científicas importantes nem investigações originais de vulto.

Para Tamagnini tal situação resulta da falta de correspondência entre a natureza da educação científica, cívica e moral ministrada às gerações sucessivas, e as necessidades práticas da vida moderna. Urge por conseguinte reformar a Instrução o que aliás está transformado em slogan que se ouve por toda a parte. Responsabiliza-se a Universidade por todos males, acusam-na de reaccionária, clerical por se encontrar entre as suas Faculdades, a Faculdade de Teologia; acusam-na de dogmática, porque os seus professores usam borla e capelo e vestem à maneira dos padres, no entanto diz Tamagnini que o

(w) A.U.C., Assentos dos Claustros, 1856-1910, pp. 101-113. 


\section{Ideal Republicano}

respeito pelas tradições é uma condição necessária à existência das nações.

Considera que as críticas que se fazem à nossa Universidade e aos nossos estudantes são no fundo as mesmas que se fazem nos outros países. Todos têm reconhecido que há um conjunto de aspirações ideais, difíceis de harmonizar, que se encontram dispersos pelos Tratados de Psicologia da Educação e cuja realização prática ainda está longe.

Voltando ao ensino em Portugal, refere-se novamente à falta de correspondência que existe entre a organização do nosso sistema educativo e as necessidades práticas da vida social motivada por um conjunto de determinadas circunstâncias a que não são alheias as características psicológicas da raça, a situação geográfica especial do país e diversos factores sociais de difícil destrinça. Urge na verdade reformar todo o sistema educativo português e não só a Universidade. Começar-se-á pelo ensino secundário donde partem os elementos que constituem os Cursos Superiores. Como poderá um professor universitário dar os seus cursos com elevação e profundidade, quando a maioria dos seus discípulos desconhece os mais elementares princípios científicos?

Uma das soluções apresentadas seria um rigoroso exame de admissão à Universidade. Ferindo assim os interesses da opinião pública, esta iria exigir dos poderes estatais uma reorganização do ensino secundário de acordo com as exigências universitárias e essas exigências não seriam mais do que gabinetes, laboratórios, salas de estudo e bibliotecas onde os professores do Liceu poderiam efectuar as suas lições de acordo com os princípios mais elementares da pedagogia moderna. Referiu-se por fim à situação económica do professorado, considerando que não há ensino que preste sem bons professores e para que os professores sejam bons é necessário que o Estado lhes pague convenientemente. Dado que muitos professores não conseguem sobreviver com o magro salário que detêm, desviam a sua atenção para outros cargos de melhor remuneração o que acarreta grande prejuízo para o ensino. É urgente reclamar que os vencimentos correspondam à natureza e dispêndio da vida social do professor, e que a opinião pública seja alertada para a desproporção que existe entre a natureza do trabalho e a remuneração recebida.

Terminou a oração de sapiência, referindo-se ao problema da educação física dos estudantes e ao papel preponderante que os exercícios físicos representam na educação das gerações $\left({ }^{28}\right)$.

D Annuário da Universidade de Coimbra, vol. CIII-CIV, 1980-1910, pp. XXI-XLIV. 


\section{Revoltas e Revoluções}

Finalmente a implantação da República trouxe a tão almejada Reforma Universitária. Mendes dos Remédios em 1912, na inauguração do ano lectivo diz:

«O que nós podíamos pedir ao Estado, o que nós queríamos ver realizado, essa aspiração, esse desejo, esse sonho, como todos os sonhos inconsistente e fugaz, aí o temos, mais além do que esperávamos».

A visão corporalizou-se. Melhor do que a Galatea de Pigmalião, esta estátua tem realidades e não é o produto duma mentalidade febril e doentia.

Está pois feita a reforma de fora para dentro, é necessário agora fazê-la de dentro para fora» $\left({ }^{29}\right)$. E na verdade o Decreto de 24-III-1911 veio a organizar a Universidade, criando ainda as de Lisboa e do Porto. Lê-se no art. $^{\circ} 1 .^{\circ}$ : «As Universidades são estabelecimentos públicos de carácter nacional, colocados sob dependência e inspecção do Ministério do Interior e dotados pelo Estado com o consenso dos municípios das regiões interessadas para o tríplice fim:

a) Fazer progredir a Ciência pelo trabalho dos seus mestres e iniciar um escol de estudantes nos métodos de descoberta e invenção científica.

b) Ministrar o ensino geral das ciências e das suas aplicações dando a preparação indispensável às carreiras que exigem uma habilitação científica e técnica.

c) Promover o estudo metódico dos problemas nacionais $\mathrm{e}$ difundir a alta cultura na massa da Nação pelos métodos de extensão universitária».

$\mathrm{O}$ artigo $3 .^{\circ}$ dizia respeito em especial à Universidade de Coimbra: «A Universidade reformada de Coimbra compreende:

a) Uma Faculdade de Ciências destinada ao ensino superior e geral das ciências matemáticas, físico-químicas e histórico-naturais e uma Faculdade de Letras destinada ao ensino das ciências psicológicas, filológicas e histórico-geográficas.

b) Faculdades destinadas a ministrar habilitações profissionais: Faculdade de Direito e Faculdade de Medicina.

c) Escolas de Aplicação - Escola de Farmácia e Escola Normal Superior respectivamente anexas à Faculdade de Medicina e às Faculdades de Ciências e Letras»».

$\mathrm{O}$ artigo $7 .^{\circ}$ determina que está confiado às Universidades o seu próprio governo económico e científico e o artigo $8 .^{\circ}$ vem consignar que as Universidades e bem assim as Faculdades e Escolas Universitárias são pessoas morais, gozando de capaci-

(M) Annuário da Universidade de Coimbra, vol. CIII, 1912-1913, p. 17. 
dade jurídica para adquirir a título gratuito ou oneroso os bens que lhe sejam transmitidos e para os administrar bem como todas as dotações que receberem segundo orçamento próprio no desenvolvimento da Ciência e usos do ensino.

Estava pois feita a reforma; pairava outro espírito sobre a Universidade que culminou com o Decreto n. ${ }^{\circ} 5.554$, de 6 de Julho de 1918, do governo de Sidónio Pais. 